\title{
Supporting Information: Persistence of SARS-CoV-2 in Water and Wastewater
}

Aaron Bivins ${ }^{1,2 \#}$, Justin Greaves ${ }^{1 \#}$, Robert Fischer ${ }^{\# 3}$, Kwe Claude Yinda ${ }^{3}$, Warish Ahmed ${ }^{4}$, Masaaki Kitajima ${ }^{5}$, Vincent Munster ${ }^{3}$, Kyle Bibby $^{1 *}$

\#These authors have contributed equally to the publication of this work.

${ }^{1}$ Department of Civil \& Environmental Engineering \& Earth Sciences, University of Notre Dame, Notre Dame, IN 46556, USA

2Environmental Change Initiative, University of Notre Dame, Notre Dame, IN 46566, USA ${ }^{3}$ Laboratory of Virology, Rocky Mountain Laboratories (RML), National Institutes of Health, Hamilton, MT 59840, USA

${ }^{4}$ CSIRO Land and Water, Ecosciences Precinct, 41 Boggo Road, Dutton Park, QLD 4102, Australia

${ }^{5}$ Division of Environmental Engineering, Hokkaido University, North 13 West 8, Kita-ku, Sapporo, Hokkaido 060-8628, Japan

*Correspondence: 156 Fitzpatrick Hall, Notre Dame, IN 46656, USA; kbibby@nd.edu

Table S1 - Physicochemical characteristics of untreated wastewater used in the study

Table S2 - Extra sum-of-squares $F$ test results for biphasic versus monophasic decay models of infectious SARS-CoV-2

Figure S1 - Linearized TCID 50 measurements

Figure S2 - Linearized SARS-CoV-2 RNA gene copy measurements

Table S3 - First-order decay rate constants for SARS-CoV-2 RNA 
Table S1 | Physicochemical characteristics of primary influent used in infectious SARS-CoV-2 persistence study.

\begin{tabular}{lc}
\hline Parameter & Measurement \\
\hline $\mathrm{pH}$ & 7.98 \\
\hline Chemical oxygen demand (mg/L) & 152.7 \\
\hline Ammonia (mg/L) & 13.3 \\
\hline Phosphorus (mg/L) & 6.0 \\
\hline total suspended solids (mg/L) & 189.6 \\
\hline
\end{tabular}

Table S2 | Extra sum-of-squares $F$ test results for comparing the monophasic and biphasic decay models of infectious SARS-CoV-2 decay for high titer wastewater and water at room temperature $\left(20^{\circ} \mathrm{C}\right)$, low titer wastewater at room temperature $\left(\mathrm{RT}, 20^{\circ} \mathrm{C}\right)$, high titer wastewater at $50^{\circ} \mathrm{C}$ and $70^{\circ} \mathrm{C}$.

\begin{tabular}{lcc}
\hline Experiment Condition & F statistic & p-value \\
\hline High Titer WW at RT & 0.0052 & 1.00 \\
\hline High Titer Water at RT & 2.8860 & 0.09 \\
\hline Low Titer WW at RT & 0.0012 & 1.00 \\
\hline High Titer WW at $50^{\circ} \mathrm{C}$ & 0.2200 & 0.88 \\
\hline High Titer WW at $70^{\circ} \mathrm{C}$ & 0.0078 & 1.00 \\
\hline
\end{tabular}



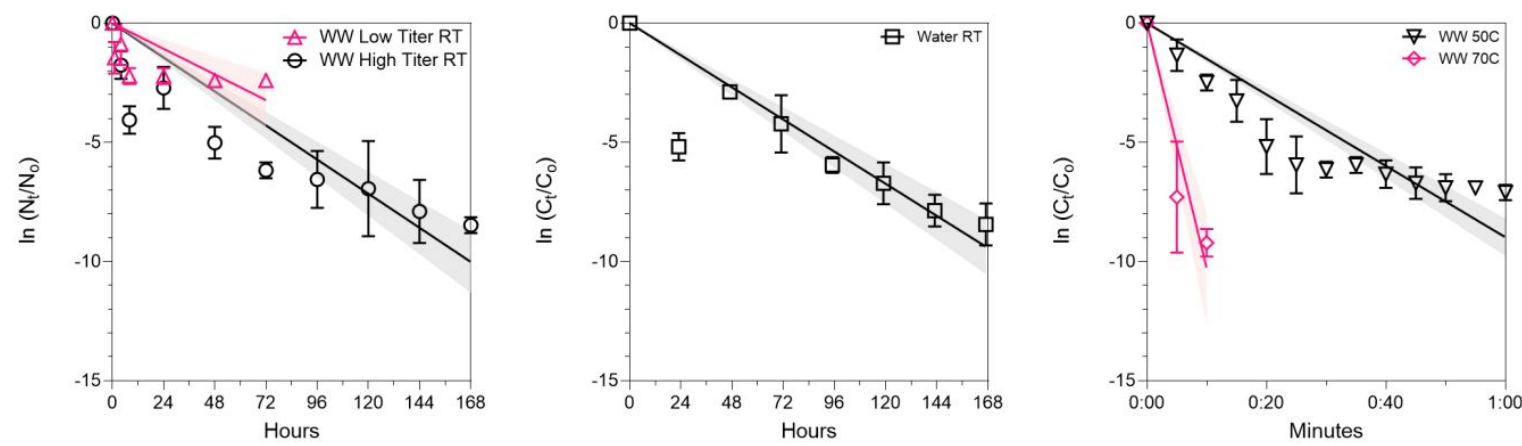

Figure S1 | TCID 50 measurements in wastewater (WW) inoculated at high and low titers (left panel) and water inoculated at high titer (center panel) incubated at room temperature $\left(20^{\circ} \mathrm{C}\right.$, RT) and WW inoculated at high titer and incubated at $50^{\circ} \mathrm{C}$ and $70^{\circ} \mathrm{C}$ transformed per equation (1) with linear regressions and the associated $95 \%$ confidence region shaded.
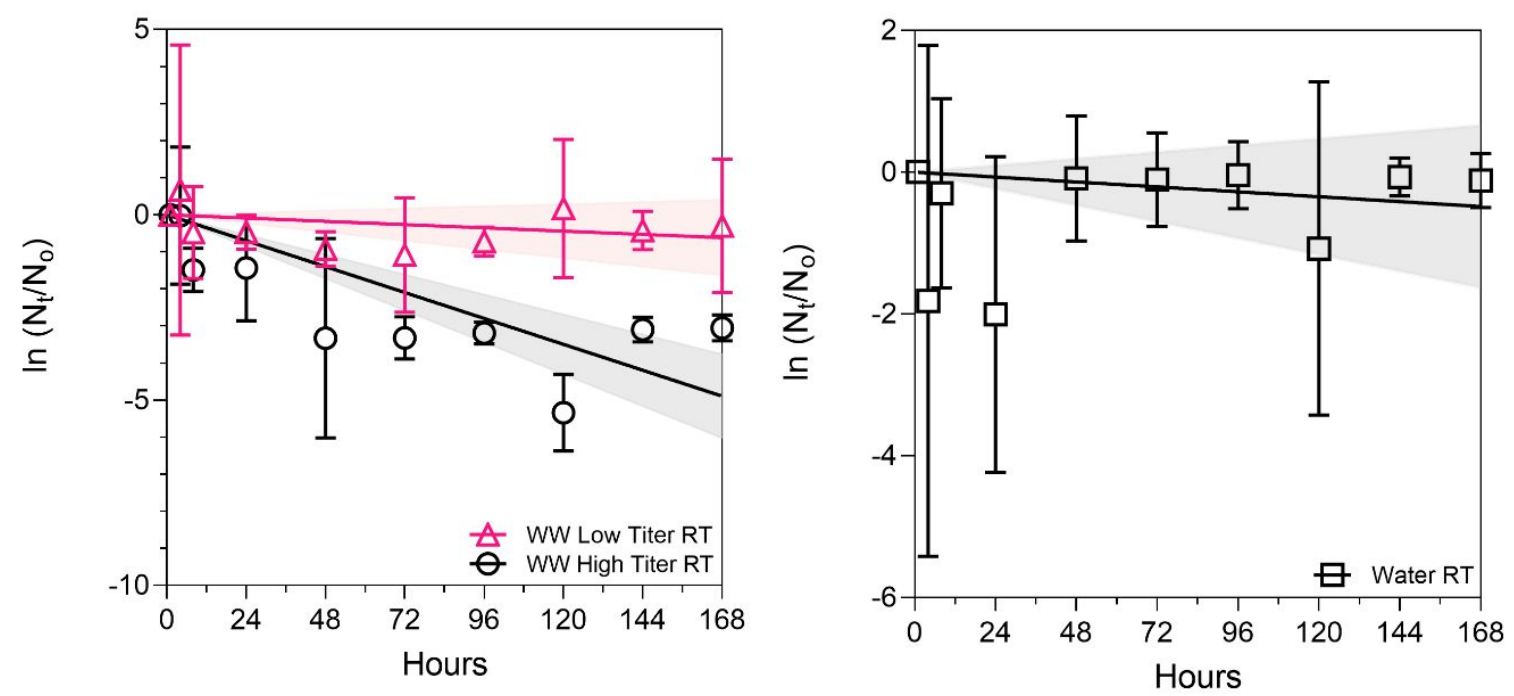

Figure S2 | Persistence of SARS-CoV-2 RNA as determined by RT-qPCR linearized per equation (1) with linear regressions and 95\% confidence regions for infectious SARS-CoV-2 inoculated in wastewater (WW) at high titer and low titer at room temperature $\left(20^{\circ} \mathrm{C}, \mathrm{RT}\right)$ (left panel) and inoculated at high titer in water at RT (right panel). RNA measurements were made from a subsample of the suspensions used to inoculate cell cultures for $\mathrm{TCID}_{50}$ measurement. 
Table S3 | First-order decay rate constants, $k$, for decay of SARS-CoV-2 RNA in wastewater (WW) inoculated with high and low titer at room temperature $\left(20^{\circ} \mathrm{C}, \mathrm{RT}\right)$ and with high titer in tap water at RT as estimated by linear regression of transformed gene copy per $\mathrm{mL}$ measurements. RNA measurements were made from the same suspensions used to inoculate cell cultures for $\mathrm{TCID}_{50}$ measurement.

\begin{tabular}{|c|c|c|c|}
\hline & $\begin{array}{c}\text { WW } \\
\text { High Titer } \\
\text { RT }\end{array}$ & $\begin{array}{c}\text { WW } \\
\text { Low Titer } \\
\text { RT } \\
\end{array}$ & $\begin{array}{c}\text { Tap Water } \\
\text { High Titer } \\
\text { RT }\end{array}$ \\
\hline $\mathrm{n}$ & 30 & 30 & 30 \\
\hline $\begin{array}{c}\mathrm{k} \\
\text { mean, } \\
95 \% \mathrm{Cl}\end{array}$ & $\begin{array}{c}0.67 \text { days }^{-1} \\
(0.54 \text { to } 0.86)\end{array}$ & $\begin{array}{c}0.09 \text { days }^{-1} \\
\left(0.00^{*} \text { to } 0.23\right)\end{array}$ & $\begin{array}{c}0.07 \text { days }^{-1} \\
\left(0.00^{*} \text { to } 0.23\right)\end{array}$ \\
\hline$r^{2}$ & 0.27 & -0.01 & -0.11 \\
\hline RMSE & 1.6 & 1.5 & 1.6 \\
\hline $\begin{array}{l}\text { Half life } \\
\text { mean, } \\
95 \% \mathrm{Cl}\end{array}$ & $\begin{array}{c}0.99 \text { days } \\
(0.81 \text { to } 1.3)\end{array}$ & $\begin{array}{l}7.9 \text { days } \\
(3.0 \text { to } \infty)\end{array}$ & $\begin{array}{c}10 \text { days } \\
(3.0 \text { to } \infty)\end{array}$ \\
\hline $\begin{array}{c}T_{90} \\
\text { mean, } \\
95 \% \mathrm{Cl}\end{array}$ & $\begin{array}{c}3.3 \text { days } \\
(2.7 \text { to } 4.3)\end{array}$ & $\begin{array}{l}26 \text { days } \\
(9.8 \text { to } \infty)\end{array}$ & $\begin{array}{l}33 \text { days } \\
(9.9 \text { to } \infty)\end{array}$ \\
\hline $\begin{array}{c}T_{99} \\
\text { mean, } \\
95 \% \mathrm{Cl}\end{array}$ & $\begin{array}{c}6.6 \text { days } \\
(5.4 \text { to } 8.6)\end{array}$ & $\begin{array}{l}52 \text { days } \\
(20 \text { to } \infty)\end{array}$ & $\begin{array}{l}67 \text { days } \\
(20 \text { to } \infty)\end{array}$ \\
\hline
\end{tabular}

${ }^{*} 95 \% \mathrm{Cl}$ truncated at 0 in the case of negative values for $k$ 